\title{
Progesterone Vaginal Insert
}

National Cancer Institute

\section{Source}

National Cancer Institute. Progesterone Vaginal Insert. NCI Thesaurus. Code C84874.

A tablet preparation formulated for vaginal administration containing a micronized synthetic form of the endogenous steroid hormone progesterone with progesterone activity. Upon vaginal insertion, progesterone binds to the progesterone receptor, resulting in dissociation of heat shock proteins, receptor phosphorylation, and transcription activation through direct or indirect interaction with transcription factors. This agent exerts inhibitory effects on estrogen by decreasing the number of estrogen receptors and increasing its metabolism to inactive metabolites. Progesterone induces secretory changes in the endometrium, decreases uterine contractility during pregnancy, and maintains pregnancy. 